\title{
Mitochondrial DNA variation within P-type cytoplasmic male sterility of Plantago lanceolata L.
}

\author{
CAROLINA F. M. GROENENDIJK †‡, JOHANNES M. SANDBRINK§, JAN VAN \\ BREDERODE $+\&$ JOS M. M. VAN DAMMET* \\ †Department of Plant Ecology and Evolutionary Biology, University of Utrecht, Padualaan 8, $3584 \mathrm{CH}$ Utrecht, \\ $\S$ Centre for Plant Breeding and Reproduction Research (CPRO-DLO), PO BOx 16, 6700 AA Wageningen and \\ १Netherlands Institute of Ecology, Centre of Terrestrial Ecology (NIOO-CTO), Boterhoekse Straat 22, 6666 GA \\ Heteren, The Netherlands
}

\begin{abstract}
MtDNA restriction fragment polymorphisms were found between cytoplasmic male-sterility types $\mathrm{P}$ and $\mathrm{R}$ of Plantago lanceolata with the homologous probe $p P l 311$ and maize mtDNA fragments derived from the regions of atp1, cox 1 and cox2. No mtDNA differences were observed between male-sterile and restored plants with the same cytoplasmic type. The consistency of the polymorphisms was studied in 83 plants from 24 natural populations in the Netherlands. Within the R-cytoplasm no mtDNA polymorphisms were found, whereas seven variant mtDNA RFLP patterns were observed within the P-cytoplasm using pPl311. We also report on a putative new cytoplasmic male-sterility type, which showed a unique RFLP pattern supporting its distinct status.
\end{abstract}

Keywords: cytoplasmic male sterility, gynodioecy, mtDNA variation, Plantago lanceolata.

\section{Introduction}

Populations of gynodioecious species consist of a mixture of male-sterile and hermaphrodite (fertility restored) plants. Male-sterile plants have a selective disadvantage relative to male-fertile plants because the former only reproduce through ovules, whereas the latter reproduce through both ovules and pollen. The gynodioecious breeding system is interesting from an evolutionary point of view because here male-sterile plants coexist with hermaphrodites in natural populations in spite of their disadvantage of not prod: ng pollen. For several gynodioecious species, the mode of inheritance of male sterility has been demonstrated to be nuclear-cytoplasmic, for example in Plantago lanceolata (Van Damme \& Van Delden, 1982; Van Damme, 1983), Beta maritima (Boutin et al., 1987), Thymus vulgaris (Belhassen et al., 1991) and Plantago coronopus (Koelewijn \& Van Damme, 1995a,b). The cytoplasmic genome is considered to cause male sterility whereas the nucleus carries the genes that restore fertility.

\$Present address: Boyce Thompson Institute for Plant Research at Cornell University, Tower Road, Ithaca, NY 14853, U.S.A.

*Correspondence. E-mail: damme@cto.nioo.knaw.nl
Theoretical models based on nuclear-cytoplasmic inheritance have been developed to explain the maintenance of male-sterile plants among hermaphrodites (Frank, 1989; Gouyon et al., 1991). The models predict a dynamic system with fluctuating frequencies of cytoplasmic and nuclear genes within a population. In order to test hypotheses that follow from the models it is necessary to assess cytoplasmic and nuclear gene frequencies in natural populations. Although considerable progress in the detection of cytoplasmic sources has been made during recent years in crop species (Kiang et al., 1993; Yamagishi \& Terachi, 1994; Riesenberg et al., 1994), experimental studies on cytoplasmic type frequencies in natural populations are still limited (Belhassen et al., 1993; Saumitou-Laprade et al., 1993; Cuguen et al., 1994).

Within natural populations of Plantago lanceolata at least two morphologically distinguishable malesterility types are found. Male-sterile frequencies lie between 0 and 10 per cent for the $\mathrm{P}$ (etaloid) type and between 0 and 22 per cent for the R(educed stamen) type. Hermaphrodites and plants with an intermediate phenotype (partially fertile) comprise the remainder of the populations (Van Damme \& Van Delden, 1982). Cytoplasmic male-sterility types 
$\mathrm{R}$ and $\mathrm{P}$ are defined genetically by differences in restoration genetics (Van Damme, 1983), and can easily be recognized in male-sterile and intermediate plants by examining their flower morphology. The cytoplasmic type of hermaphrodite plants can only be determined indirectly by crossing the plant to maintainers of each sterility type and examining the flower morphology of the male-sterile progeny (Van Damme \& Van Delden, 1982). It is therefore highly desirable to develop methods that quickly distinguish the cytoplasmic type of nonflowering and hermaphrodite plants. It is now commonly accepted that mitochondria rather than chloroplasts are involved in male sterility (reviewed by Hanson, 1991). Rouwendal et al. (1987) have shown that both cytoplasmic male-sterility types in $P$. lanceolata can be distinguished at mitochondrial DNA (mtDNA) and mtRNA levels after hybridization with the $P$. lanceolata mtDNA probe $p P l 311$.

The research described in this paper has three aims: (i) to study additional mtDNA variation between and within the two known cytoplasmic male-sterility types, using $p P l 311$ and heterologous mtDNA probes; (ii) to study the consistency of the P- and R-type specific mtDNA RFLP patterns by analysing plants with known cytoplasmic malesterility type from different natural populations; and (iii) to characterize a putative new cytoplasmic malesterility type An6.

\section{Materials and methods}

\section{Plant material}

In this study $88 P$. lanceolata plants were examined. From 24 natural populations in the Netherlands (Table 1), 83 plants were collected for which the cytoplasmic type was determined by flower morphology. Plants were either of male-sterile or of intermediate sex phenotype. In addition, five plants, Wd876 (restored; R-cytoplasm), Wd875 (malesterile; R-cytoplasm), An932 (restored; P-cytoplasm), Wd874 (male-sterile; P-cytoplasm) and An6 (hermaphrodite; cytoplasmic type unknown) were derived from a crossing program (Van Damme, unpublished data), and were grown from seeds in the greenhouse. Cytoplasmic types of the hermaphrodites $\mathrm{Wd} 875$ and $\mathrm{Wd} 876$ were known from breeding.

\section{Preparation of total DNA}

Total DNA was prepared from leaves according to Rogers \& Bendich (1985) with several modifications. About $1 \mathrm{~g}$ of leaves was ground in liquid nitrogen.
To the powdered plant tissue $5 \mathrm{~mL}$ of $1 \times$ CTAB extraction buffer (1 per cent hexadecyltrimethylammonium bromide (CTAB), $0.7 \mathrm{M} \mathrm{NaCl}, 10 \mathrm{~mm}$ EDTA, $50 \mathrm{~mm}$ Tris- $\mathrm{HCl}, \mathrm{pH} 8.0$ ) were added and after thorough mixing $10 \mu \mathrm{L}$ beta-mercaptoethanol were added to each sample. After incubation for $30 \mathrm{~min}$ at $65^{\circ} \mathrm{C}$, the samples were extracted twice with chloroform:isoamyl alcohol (24:1). The DNA was precipitated for $30 \mathrm{~min}$ at room temperature by the addition of 0.6 vol. isopropanol and collected by centrifugation. The pellet was dissolved in $200 \mu \mathrm{L}$ $\mathrm{TE}$ and centrifuged to remove residual insoluble material and polysaccharides. DNA samples were stored at $4^{\circ} \mathrm{C}$.

\section{Preparation of total RNA}

Total RNA was isolated from leaves as described by Verwoerd et al. (1989) with several modifications. Leaves $(1 \mathrm{~g})$ were ground in liquid nitrogen and $8 \mathrm{~mL}$ hot $\left(80^{\circ} \mathrm{C}\right)$ extraction buffer [0.2 $\mathrm{M} \mathrm{NaOAc}, \mathrm{pH}$ $5.0,1$ per cent SDS, $10 \mathrm{~mm}$ EDTA, $\mathrm{pH} 8.0$ mixed with water-saturated phenol (1:1)] were added. The mixture was vigorously shaken for $5 \mathrm{~min}$ at room temperature and twice extracted with $4 \mathrm{~mL}$ chloroform:isoamyl alcohol (24:1). After centrifugation the aqueous phase was mixed with one volume of $4 \mathrm{M}$ $\mathrm{LiCl}$. RNA was precipitated overnight at $4^{\circ} \mathrm{C}$ and collected by centrifugation. The pellet was washed once with $2 \mathrm{M} \mathrm{LiCl}$ and twice with 80 per cent ethanol. After drying, the RNA was dissolved in water and stored at $-20^{\circ} \mathrm{C}$.

\section{Restriction endonuclease digestions and filter hybridizations}

Restriction enzymes (Pharmacia) were used in a 10 -fold excess under conditions recommended by the manufacturer. DNA fragments were separated in 0.8 per cent agarose gels in $0.5 \times \mathrm{TBE}$ and transfered to Hybond (Amersham) according to the manufacturer's recommendations. DNA labelling and detection were carried out with a nonradioactive DNA labelling and detection kit (Boehringer Mannheim). To detect alkaline phosphatase activity, AMPPD (Tropix) was used (Kreike et al., 1990). Hybridization took place at $63^{\circ} \mathrm{C}$ and the blots were subsequently washed in $2 \times \mathrm{SSC}, 0.1$ per cent SDS and $0.2 \times \mathrm{SSC}, 0.1$ per cent SDS at room temperature and $63^{\circ} \mathrm{C}$, respectively.

RNA was size fractionated in 6 per cent formaldehyde- 1.5 per cent agarose gels in $1 \times$ TAE. The RNA was transfered to nitrocellulose (Amersham) under high salt conditions $(20 \times$ SSC). For probe labelling,

(C) The Genetical Society of Great Britain, Heredity, 78, 75-83. 
Table 1 Mitochondrial DNA RFLP patterns of Plantago lanceolata with the unidentified open reading frame probe $p P l 311$, showing 88 plants from 24 natural populations in the Netherlands

\begin{tabular}{|c|c|c|c|c|c|c|c|c|c|c|c|}
\hline & \multirow[b]{2}{*}{ Population } & \multicolumn{10}{|c|}{ RFLP pattern } \\
\hline & & $\mathbf{R}$ & P1 & $\mathrm{P} 2$ & P3 & P4 & P5 & P6 & P7 & An6 & Total \\
\hline Wd & Westduinen & $2^{*}$ & - & - & - & 一 & - & 1 & - & - & $2 \dagger$ \\
\hline UU & Utrecht & 2 & 2 & - & - & - & - & - & - & - & 2 \\
\hline Or & Flevopolder & 1 & 2 & - & - & - & - & - & - & - & 2 \\
\hline HK & Hank & - & 2 & - & - & - & - & - & - & - & 1 \\
\hline An & Anloo & - & 3 & - & - & 2 & - & - & - & 1 & 3 \\
\hline $\mathrm{Na}$ & Voorne & 6 & 2 & 2 & - & - & - & - & - & - & 3 \\
\hline ZB & Zevenbergseweg & 2 & - & 1 & - & - & - & - & - & - & 2 \\
\hline Rut & Rutten & 2 & - & 1 & - & - & - & - & - & - & 2 \\
\hline Mep & Meppelerdiep & - & - & 2 & - & - & - & - & - & - & 1 \\
\hline DD & Hengelo & 3 & - & 1 & - & - & - & - & - & - & 1 \\
\hline VL2 & Vlaardingen & - & - & 2 & 4 & - & - & - & - & - & 2 \\
\hline Bal & Balk & 2 & - & - & 1 & 1 & 1 & - & - & - & 4 \\
\hline Wor & Workum & 1 & - & - & 1 & - & - & - & - & - & 2 \\
\hline $\mathrm{Me}$ & Merrevliet & - & - & - & - & - & - & - & 3 & - & 1 \\
\hline Oog & Schier & 1 & - & - & - & - & - & 1 & - & - & 2 \\
\hline $\mathrm{BR}$ & Bruuk & 1 & - & - & - & - & - & - & - & - & 1 \\
\hline Ht1 & Heteren & 6 & - & - & - & - & - & - & - & - & 1 \\
\hline Me1 & Merrevliet & 6 & - & - & - & - & - & - & - & - & 1 \\
\hline $\mathrm{P}$ & Piek & 2 & - & - & - & - & - & - & - & - & 1 \\
\hline $\mathrm{Pa}$ & Papendal & 2 & - & - & - & - & - & - & - & - & 1 \\
\hline ST & Amersfoort & 3 & - & - & - & - & - & - & - & - & 1 \\
\hline VL1 & Vlaardingen & 5 & - & - & - & - & - & - & - & - & 1 \\
\hline WH & Wolfheze & 1 & - & - & - & - & - & - & - & - & 1 \\
\hline $\mathrm{ZF}$ & Zuid Flevo & 4 & - & - & - & - & - & 一 & - & - & 1 \\
\hline Total & & $19 \ddagger$ & 5 & 6 & 3 & 2 & 1 & 2 & 1 & 1 & \\
\hline
\end{tabular}

*Number of plants per RFLP pattern.

$\nmid$ Number of cytoplasmic types and P-variants per population.

$\ddagger$ Number of populations per RFLP pattern.

hybridization and detection the ECL gene detection system (Amersham) was used.

\section{Homologous and heterologous probes}

The mitochondrial genes used as probes were pPl311, which probably codes for an unidentified open reading frame from $P$. lanceolata cytoplasmic type P (Rouwendal et al., 1987), ATPase subunit A (atp1, Isaac et al., 1985a), and cytochrome c oxidase subunits 1 (cox1, Isaac et al., 1985b) and 2 (cox2, Fox $\&$ Leaver, 1981) from maize.

\section{Results}

\section{Mitochondrial DNA analysis of the P-and R-cytoplasm}

Previous results have shown the presence of a unique $1.1 \mathrm{~kb}$ Bam HI mtDNA fragment in P-cyto- plasmic plants after hybridization with pPl311 (Rouwendal et al., 1987). To detect additional mtDNA variation between the $\mathrm{P}$ - and $\mathrm{R}$-cytoplasms, total DNA of Wd874, Wd875, Wd876, and An932 was digested with BglII, DraI, EcoRI, EcoRV or HindIII, and hybridized with pPl311 or maize mtDNA probes corresponding to the ATPase alpha subunit (atp1) and cytochrome c oxidase subunit 1 (cox 1$)$.

Each of the five enzymes revealed RFLPs, indicative of different genomic environments for pPl311 in P- and R-cytoplasms (Fig. 1a, lanes $1 / 2$ and 3/4; Table 2). Four conclusions emerge from these observations. First, some of the sequences contained within pPl311 are present in more than one copy on the mitochondrial genome. For example, HindIII digestion revealed six hybridizing bands for the P-cytoplasm and three for the R-cytoplasm. Both cytoplasmic types shared several bands, depending

(c) The Genetical Society of Great Britain, Heredity, 78, 75-83. 


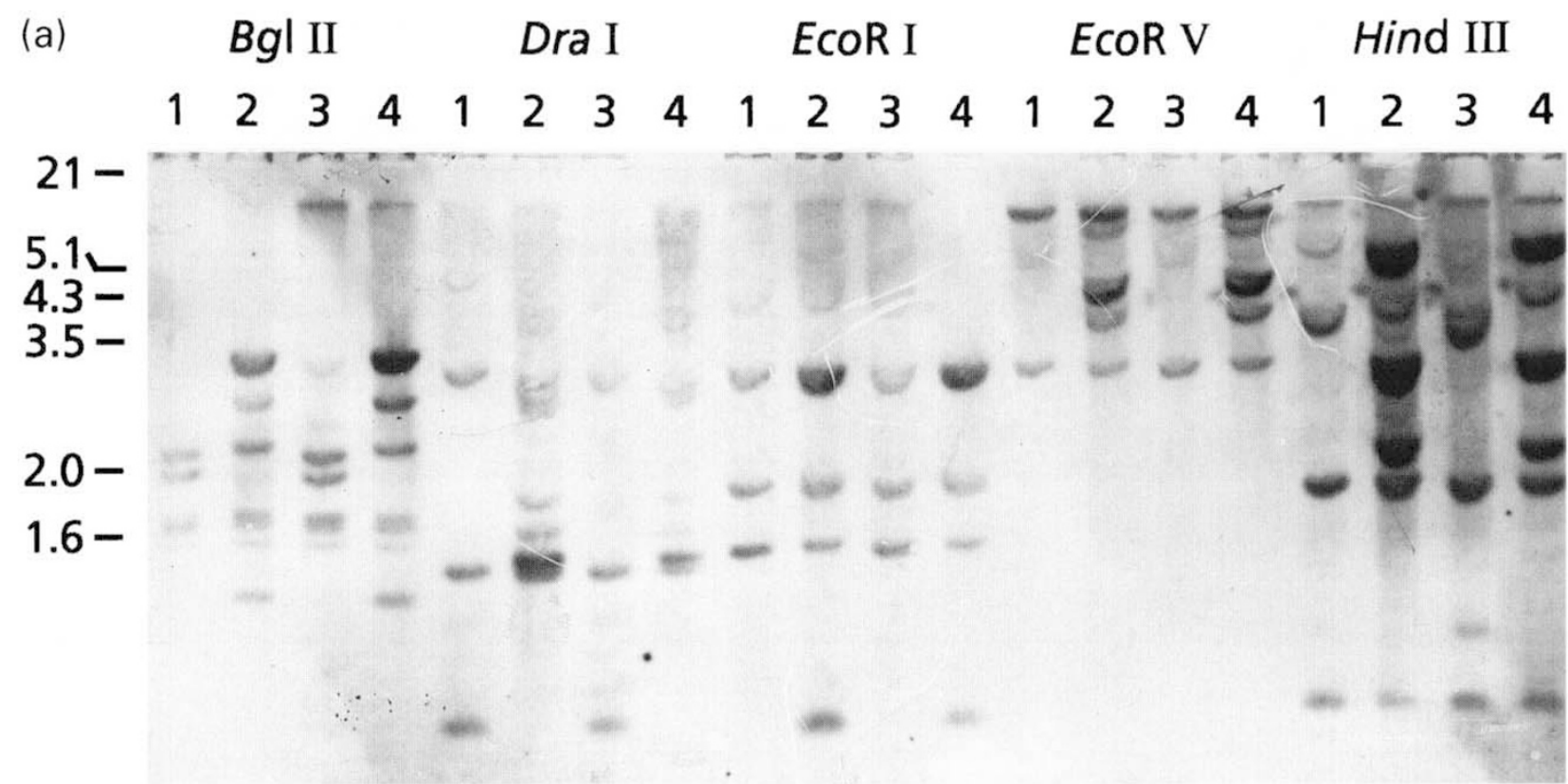

(b) $B g \mid$ II Dra I EcoR I ECOR V Hind III

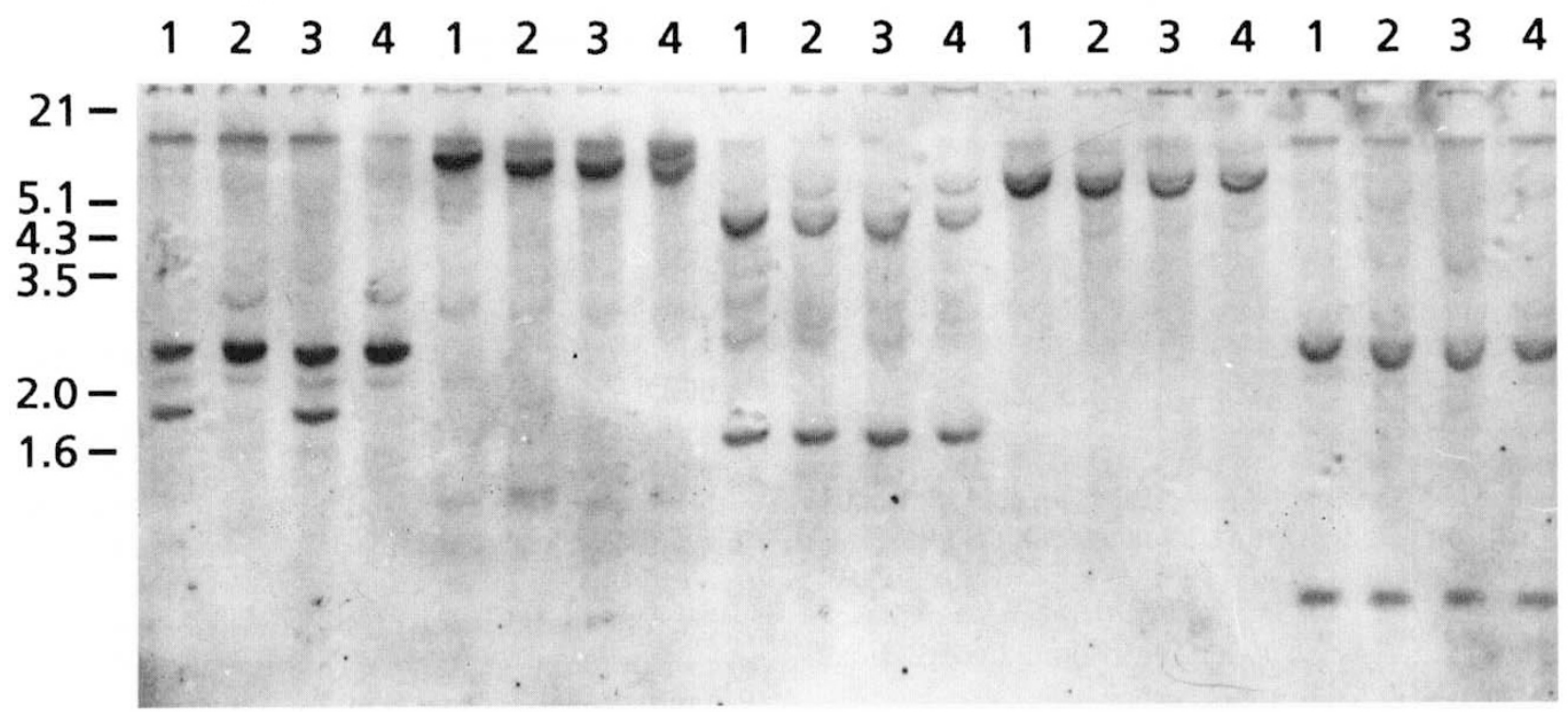

Fig. 1 Southern hybridization of cytoplasms $\mathrm{P}$ and $\mathrm{R}$ with (a) the unidentified open reading frame $p P l 311$ from Plantago lanceolata and (b) the gene-specific probe from maize coding for subunit I of the cytochrome c oxidase (coxI). Total DNAs were digested with BglII, DraI, Eco RI, EcoRV or HindIII. 1, Wd875 (male-sterile; R-cytoplasm); 2, Wd874 (malesterile; P-cytoplasm); 3, Wd876 (restored; R-cytoplasm); 4, An932 (restored; P-cytoplasm). An internal DraI site in pPl311 partly explains the complex hybridization pattern with this enzyme. Molecular weights in all figures are given in kb, and were derived from Hin dIII/Eco RI-digested phage lambda DNA. 
Table 2 Number of hybridizing bands following digestion of total DNAs from P- and R-cytoplasms of Plantago lanceolata and hybridization with several mtDNA probes

\begin{tabular}{|c|c|c|c|c|c|c|c|c|c|c|c|c|c|c|c|}
\hline & \multicolumn{3}{|c|}{ BgIII } & \multicolumn{3}{|c|}{ DraI } & \multicolumn{3}{|c|}{ Eco RI } & \multicolumn{3}{|c|}{ EcoRV } & \multicolumn{3}{|c|}{ HindIII } \\
\hline & $P$ & $\mathrm{R}$ & C & $P$ & $\mathrm{R}$ & C & $\mathrm{P}$ & $\mathrm{R}$ & C & $P$ & $\mathrm{R}$ & C & $P$ & $\mathrm{R}$ & $\mathrm{C}$ \\
\hline pPl311 & 8 & 5 & 3 & 7 & 3 & 2 & 4 & 3 & 3 & 5 & 2 & 2 & 6 & 3 & 2 \\
\hline $\operatorname{cox} 1$ & 1 & 2 & 1 & 1 & 1 & 1 & 2 & 2 & 2 & 1 & 1 & 1 & 2 & 2 & 2 \\
\hline $\cos 2$ & 4 & 3 & 3 & 4 & 4 & 2 & 2 & 2 & 1 & 1 & 1 & 0 & ND & ND & ND \\
\hline $\operatorname{atp} A$ & 2 & 2 & 2 & 2 & 2 & 2 & 2 & 1 & 1 & 2 & 2 & 2 & 2 & 2 & 2 \\
\hline
\end{tabular}

$\mathrm{C}$ indicates the number of fragments in common.

on the restriction enzyme used. The results are indicative of at least four copies of the pPl311 sequence in the P-cytoplasm and two in the R-cytoplasm. Secondly, RFLP patterns of P (Fig. 1a, lanes 2 and 4) show more hybridizing bands than $R$ (lanes 1 and 3) for all restriction enzymes examined. This suggests that the organization of $p$ Pl311-homologous sequences is more complex in $\mathrm{P}$ than in $\mathrm{R}$ (Table 2). Thirdly, variable hybridization intensities are observed within P. Unusually strong hybridizing bands include a $1.75 \mathrm{~kb}$ DraI fragment, a $15 \mathrm{~kb}$ Eco RV fragment and a $5.0 \mathrm{~kb}$ HindIII fragment. Fourthly, differences in stoichiometry or hybridization strength are seen when comparing the RFLP patterns of the two cytoplasmic types (the $3.5 \mathrm{~kb}$ EcoRI fragment). Alternatively, this could result from two comigrating fragments in $\mathrm{P}$.

No genomic rearrangements were observed for coxl between the $\mathrm{P}$ - and R-cytoplasms, although a RFLP is seen using BglII (Fig. 1b, Table 2), with 2.4 $\mathrm{kb}$ and $1.9 \mathrm{~kb}$ fragments hybridizing in $\mathrm{R}$, and a single $2.4 \mathrm{~kb}$ fragment hybridizing in $\mathrm{P}$. This suggests that $\mathrm{R}$ has two cox1 copies of which one has an internal BglII site. A third fragment would be predicted for $\mathrm{R}$, but was not observed. This may indicate that the second coxl copy is truncated, or that the second fragment is too small to be detected using our gel system. Because no differences were observed using four other enzymes, the data favour the second possibility.

Hybridization with the atp $A$ gene revealed two copies of this gene in each cytoplasmic male-sterility type (data not shown). The genomic environment of atp $A$ in the $\mathrm{P}$ - and $\mathrm{R}$-cytoplasms is similar, with identical fragments identified following digestion with $B g l \mathrm{II}, D r a \mathrm{I}, E c o \mathrm{RV}$ or HindIII. Eco RI digestion revealed an RFLP, with one fragment hybridizing in $\mathrm{R}(3.8 \mathrm{~kb})$, and two hybridizing fragments in $\mathrm{P}(3.8 \mathrm{~kb}$ and $3.5 \mathrm{~kb})$. This result suggests that $\mathrm{P}$ has an internal Eco RI site in one atp $A$ copy, resulting in a hybridizing $3.5 \mathrm{~kb}$ fragment and an undetected small fragment. Alternatively, only one copy could be assumed for both $\mathrm{P}$ and $\mathrm{R}$ with internal restriction sites for all tested enzymes, except that an internal Eco RI site exists uniquely in P.

For all three probes analysed, no differences were observed between male-sterile and restored plants with the same cytoplasmic type (Fig. 1, lanes $1 / 3$ and $2 / 4$ ). Therefore, it can be concluded that fertility restoration has no effect on mitochondrial genome structure in the vicinity of $p P l 311$, atp $A$ and coxl, nor did it affect the differences in hybridization intensities observed both within and between cytoplasmic types.

\section{Mitochondrial RNA analysis of the $P$ - and R-cytoplasm}

We studied the effect of mtDNA structure on the expression of the open reading frames $p P l 311$, cox 1 and $\operatorname{cox} 2$ by hybridizing probes encoding these regions with filter-bound total RNA of An932, Wd874, Wd875 and Wd876. Expression of pPl311 differed between the two cytoplasmic types. As previously reported (Rouwendal et al., 1987), we observed a P-specific transcript of $1250 \mathrm{nt}$ and an R-specific transcript of 1100 nt (data not shown). A $930 \mathrm{nt}$ transcript that was sometimes detected in $\mathrm{P}$ plants tested by Rouwendal et al. (1987) was not present in our samples. No difference between the $\mathrm{P}$ - and R-cytoplasms was found for $\operatorname{cox} 1$ and $\operatorname{cox} 2$ transcripts (data not shown). At least five major transcripts were observed for cox 1 , ranging between $1800 \mathrm{nt}$ and $950 \mathrm{nt}$ and at least four major transcripts were detected for cox2, ranging from $1820 \mathrm{nt}$ to $1000 \mathrm{nt}$. No difference in transcript patterns was observed between male-sterile and restored plants with the same cytoplasmic type. Thus, fertility 
restorer genes apparently have no effect on the transcription of these three open reading frames in leaves.

\section{Analysis of a putative new cytoplasmic male- sterility type}

One of the plants analysed in this study is An6, which was collected in the Anloo population in the north-eastern part of the Netherlands. An6 has not been classified as having one of the two known cytoplasmic types, because extensive crossing did not yield male-sterile progeny. An6 acts as a maintainer of the P-cytoplasm, implying that it does not have P-cytoplasm (Van Damme, unpublished). However, results obtained by Rouwendal et al. (1987) give An6 the P-cytoplasm status because its mtDNA contains the $1.1 \mathrm{~kb} p P l 311$-hybridizing Bam $\mathrm{HI}$ fragment, which is unique to the P-cytoplasm. A single pPl311-homologous transcript of $880 \mathrm{nt}$ was found (data not shown), which agrees with previously published results (Rouwendal et al., 1987).

To study the mtDNA of An6, total DNAs of An6, An932 (restored P) and Wd876 (restored R) were digested with $B a m \mathrm{HI}, B g l \mathrm{I}, B g l \mathrm{II}, D r a \mathrm{I}, E c o$ RI, Eco RV, or HindIII, and hybridized with the four mtDNA probes pPl311, cob, cox 1 and cox2 (Table $3)$. For 10 probe-enzyme combinations, the hybridization patterns of the three cytoplasmic types were identical, as indicated by a ' 0 ' in Table 3 . For 14 probe-enzyme combinations, the hybridization patterns of An6 were identical with those of P1, but different from those of $\mathrm{R}$ (indicated by a ' $\mathrm{P} 1$ ' in Table 3). For the remaining four probe-enzyme combinations, the hybridization pattern for An6 was unique.

Table 3 MtDNA RFLP pattern comparison between An6, and the P1- and R-cytoplasms of Plantago lanceolata

\begin{tabular}{lcccc}
\hline & $c o b$ & $c o x I$ & $c o x 2$ & $p P l 311$ \\
\hline Bam HI & $\mathrm{P} 1$ & 0 & $\mathrm{P} 1$ & $\mathrm{P} 1$ \\
BglI & $\mathrm{P} 1$ & 0 & 0 & $\mathrm{P} 1$ \\
BglII & $\mathrm{P} 1$ & $\mathrm{P} 1$ & 0 & An6 \\
DraI & $\mathrm{P} 1$ & 0 & $\mathrm{P} 1$ & An6 \\
Eco $\mathrm{RI}$ & $\mathrm{P} 1$ & 0 & $\mathrm{P} 1$ & $\mathrm{P} 1$ \\
Eco RV & 0 & 0 & $\mathrm{P} 1$ & An6 \\
HindIII & $\mathrm{P} 1$ & 0 & 0 & An6 \\
\hline
\end{tabular}

0: No RFLP differences between P1, R and An6.

P1: RFLP pattern of An6 is identical to P1 but different from $\mathrm{R}$.

An6: RFLP pattern of An6 is unique.

\section{Mitochondrial DNA variation within the $P$ - and $R$-cytoplasmic types}

To study the consistency of mtDNA RFLPs specific to the P- and R-cytoplasmic types, we compared mtDNA RFLPs of 83 plants sampled from 24 Dutch populations (Table 1). The cytoplasmic type of each plant was assessed by its flower morphology. An6, An932, Wd874, Wd875, and Wd876 were also included in this study. Total DNA was digested with HindIII and hybridized with pPl311. This enzyme was chosen because it reveals more RFLPs than BglII, Dra I, Eco RI or Eco RV.

No variation in mtDNA hybridization patterns was observed among 52 plants carrying the R-cytoplasm, indicating that no genomic rearrangements have occurred within this cytoplasmic type in the vicinity of pPl311 (data not shown). In contrast, seven different hybridization patterns could be distinguished among 35 P-cytoplasmic plants (Fig. 2), and these patterns were termed P1-P7. $\mathrm{P} 1-\mathrm{P} 7$ differed in both number and relative migration of hybridizing fragments. Two fragments of 1.9 $\mathrm{kb}$ and a weak $4.8 \mathrm{~kb}$ were shared among the seven variant patterns, of which one fragment $(1.9 \mathrm{~kb})$ was also shared with An6 and R. An6 had a unique hybridization pattern among the 87 plants tested.

The variant P-patterns are apparently randomly distributed over populations in the Netherlands (Table 1). Variants P1 and P2 are found in five and six different populations, respectively, which are dispersed throughout the Netherlands. For variant $\mathrm{P} 1$, the distance between the most distant populations, Anloo (An) in the north-east and Voorne (Na) in the south-west, is about $300 \mathrm{~km}$. On the other hand, one population may include several variant P-patterns, as is seen for the populations Anloo with variants P1, P4, and An6, and Balk (Bal) with variants $\mathrm{P} 3, \mathrm{P} 4$, and $\mathrm{P} 5$.

Hybridization of total RNA with pPl311 did not reveal any difference in expression for the seven P-variants. All variants showed a major transcript of $1250 \mathrm{nt}$ and a minor one of $800 \mathrm{nt}$ (data not shown).

\section{Relationships between different cytoplasms}

Using the restriction enzyme-probe combination HindIII-pPl311, the An6, R-cytoplasm and the seven P-variants could be distinguished (Fig. 2). Using Eco RI or Eco RV, some P-variants could be clustered together on the basis of identical RFLP patterns. This RFLP information was used to study the relatedness between the variant P-cytoplasms and the two other cytoplasmic types. The R-cyto- 


\section{$\begin{array}{lllllllllllllll}1 & 2 & 3 & 4 & 5 & 6 & 7 & 8 & 9 & 10 & 11 & 12 & 13 & 14 & 15\end{array}$}

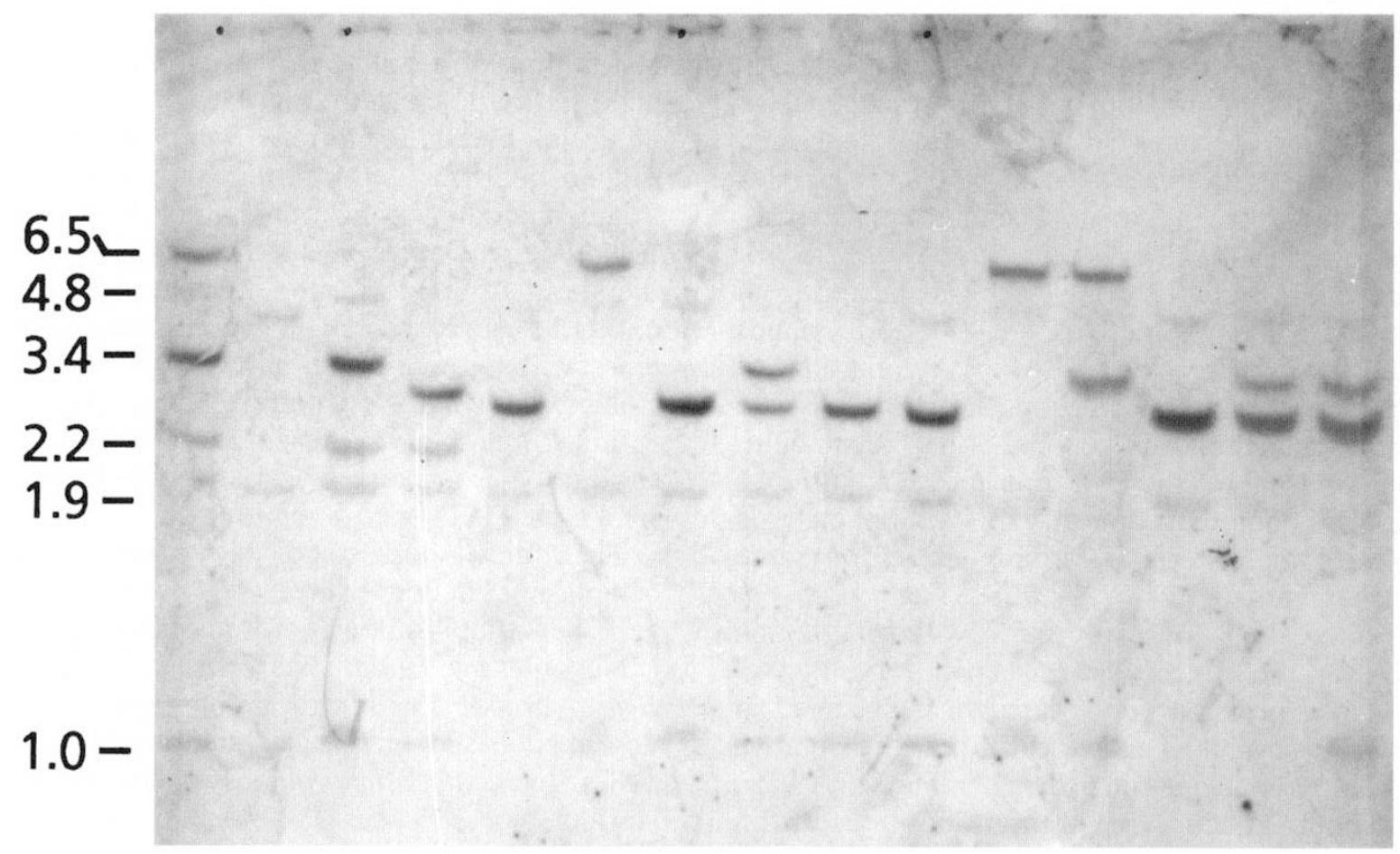

Fig. 2 Southern blot hybridization of total DNAs from different P-cytoplasmic plants with the unidentified open reading frame $p P l 311$ from Plantago lanceolata. Total DNAs were digested with HindIII. 1, An932 (P1); 2, Wd875 (R); 3, Wd872 (P6); 4, An6 (An6); 5, An76 (P4); 6, Me100 (P7); 7, Na5 (P2); 8, VL2-2 (P3); 9, VL2-6 (P2); 10, DD4 (P2); 11, Me858 (P7); 12, HK1 (P1); 13, Bal1 (P4); 14, Bal2 (P5); 15, Bal3 (P3).

plasm is clearly distinguishable from $\mathrm{P}$ and An6 using a variety of probe-enzyme combinations (Table 3). This demonstrates that $\mathbf{R}$ is a distinct cytoplasmic male-sterility type both phenotypically and at the mtDNA level. P1 and An6 appear to have identical $B a m \mathrm{HI}, B g l \mathrm{I}$ and Eco RI hybridization patterns using $p P l 311$, but different patterns using BglII, Dra I, Eco RV or HindIII and pPl311.

\section{Discussion}

In previous studies genetic analysis has been used to distinguish two cytoplasmic male-sterility types with distinct male-sterile flower characteristics in natural populations of $P$. lanceolata. Plants with the P-cytoplasm are characterized by petaloid stamens, whereas the R-type has stamens which are reduced in size (Van Damme \& Van Delden, 1982). Here these two cytoplasmic male-sterility types have been characterized for their mtDNA. In addition, a putative new cytoplasmic male-sterility type An6 (Van Damme, unpublished) has been included in the study. The results presented in this paper show that the mitochondrial genomes of the P- and R-cytoplasms differ extensively at the mtDNA level. These mtDNA differences suggest that the two cytoplasmic types of $P$. lanceolata have been separated for a considerable time. The An6 line clearly showed unique RFLP patterns which supports its status as a putative new cytoplasm. In a parallel study genetic evidence is given to confirm the cytoplasmic malesterility status of An6 (A. A. De Haan et al., unpublished). The similarity between An6 and mtDNA pattern P1 suggests that either the An6 cytoplasm has arisen from $\mathrm{P} 1$, or alternatively, that $\mathrm{P} 1$ arose from An6. Because An6 is found in a single population, whereas $\mathrm{P} 1$ is present in five widely dispersed populations, the first possibility is the most likely.

Although no differences in transcription patterns were observed between $\mathrm{P}$ and $\mathrm{R}$ for $\operatorname{cox} 1$ and $\operatorname{cox} 2$ (not determined for An6), genomic rearrangements in the vicinity or even within pPl311-homologous sequences of $\mathrm{P}, \mathrm{R}$ and An6 have apparently led to a change in transcription of this open reading frame. 
This variation in the expression of the $p P l 311$ open reading frame raises the possibility that the expression of this ORF plays a role in flower development. P-type male sterility is caused by a homeotic mutation whereby stamens and petals are changed into an eight-lobed corolla. In R-type male sterility, changes leading to male sterility occur at a later stage of anther development, in or around meiosis, leading to reduced anthers.

Examination of RFLPs of 88 plants collected from $24 P$. lanceolata populations in the Netherlands revealed seven patterns within the P-cytoplasm, but no variation within the $\mathrm{R}$-cytoplasm. It is possible that the $\mathrm{R}$ mitochondrial genome is less recombinogenic than that of the P-cytoplasm. The mtDNA variation is not correlated with sex phenotype because all male-sterile P-variants have the same flower characteristics.

An interesting observation is that although mtDNA variation for $p P l 311$ exists within the P-cytoplasm, the expression of this locus is unchanged in the seven P-variants. This indicates that the putative recombinational events underlying the mtDNA variation do not influence the transcription pattern on pPl311.

Our results show that different P-variants are found within a single population and that single $\mathrm{P}$-variants are found in several populations. Two alternative hypotheses might explain this distribution pattern. The first hypothesis is that the variant patterns arose only once as a result of mitochondrial recombination, which was followed by spatial distribution over populations by seed dispersal. For example, $\mathrm{P} 2$ is found in six populations widely apart within the Netherlands, whereas P4 is found in two populations only $70 \mathrm{~km}$ apart, which would suggest that the recombinational events leading to $\mathrm{P} 4$ have occurred later in evolution. In the second hypothesis, the variant P-types arose more than once, i.e. as often as they are found, in different populations. This hypothesis assumes that the mitochondrial genome includes a number of reiterated sequences, which mediate mtDNA rearrangements that could emerge repeatedly in different populations. This hypothesis thus emphasizes recombination rather than seed dispersal.

Different RFLPs within a related group of cytoplasmic types is a possible indicator of additional cytoplasmic types. For species such as maize and Vicia faba, mtDNA variation within the fertile cytoplasm has been described (Levings \& Pring, 1977; Kemble et al., 1983; McNay et al., 1983; Negruk \& Kaushik, 1988). Variation within cytoplasmic types has been reported by several authors. Within the C group of male-sterile maize, mtDNA restriction fragment differences were observed by Pring et al. (1987). All variants could be restored by the same restoration of fertility gene Rf4. In Beta vulgaris, male-sterile lines with the Owen cytoplasm from different breeding stations were shown to have similar but not identical mitochondrial restriction fragment and hybridization patterns (Weihe et al., 1991). Genetic analysis, which is required to confirm the status of a cytoplasmic male-sterility type based on RFLP analysis, did not reveal new cytoplasmic types within the variant mtDNA patterns in these studies. To what extent the observed RFLP variants within $P$. lanceolata represent new cytoplasmic malesterility types is examined in an accompanying study (A. A. De Haan et al., submitted).

Theoretical models typically assume only a few cytoplasmic male-sterility types with one restorer gene per cytoplasmic type within natural populations (Gouyon et al., 1991; however, see Frank, 1989). In Beta maritima, two cytoplasmic types have been described based on genetic analysis (Boutin et al., 1987). In Plantago lanceolata two cytoplasmic malesterility types, $\mathrm{P}$ and $\mathrm{R}$, have been described with three and five fertility-restoration genes for $\mathrm{P}$ and $\mathrm{R}$, respectively (Van Damme \& Van Delden, 1982; Van Damme, 1983). For $P$. coronopus two cytoplasmic male-sterility types exist with a minimum of five restorer genes for each cytoplasmic type (Koelewijn \& Van Damme, 1995a,b). Although some models reasonably agree with experimental data, they do not exclude the presence of more than two cytoplasmic male-sterility types in a population. In fact, our knowledge of the number of cytoplasmic malesterility types in natural populations is still limited.

In order to study the maintenance of male-steriles among hermaphrodites in natural populations and the dynamics of this system, information is needed with respect to spatio-temporal cytoplasmic frequencies. Our observed molecular variation can be exploited to estimate these frequencies, thereby giving a better understanding of the evolutionary dynamics of the sexual system gynodioecy.

\section{Acknowledgements}

C.F.M.G. was supported by the Netherlands Foundation of Life Sciences (SLW), with financial aid from the Netherlands Organization for the Advancement of Research (NWO). We would like to thank Dr G. J. A. Rouwendal for providing pPl311 and Dr C. J. Leaver for providing the heterologous mtDNA probes. We also thank Anita de Haan and Dr D. B. Stern for critically reading the 
manuscript. Publication no. 2140 Netherlands Institute of Ecology, NIOO-CTO, Heteren.

\section{References}

BELHASSEN, E., DOMMÉE, B., ATLAN, A., GOUYON, P.-H., POMENTE, D., ASSOUAD, M. W. AND COUVET, D. 1991. Complex determination of male sterility in Thymus vulgaris L. Genetic and molecular analysis. Theor. Appl. Genet., 82, 137-143.

Belhassen, E., ATlaN, A., COUVET, D., GOUYON, P.-H. AND QUÉTIER, F. 1993. Mitochondrial genome of Thymus vulgaris $\mathrm{L}$. (Labiate) is highly polymorphic between and among natural populations. Heredity, 71, 462-472.

Boutin, V., PANNEBECKER, G., ECKE, W., SCHEWE, G., SAUMitou-laprade, P., JEAN, R. ET $A L$. 1987. Cytoplasmic male sterility and nuclear restorer genes in a natural population of Beta maritima: genetical and molecular aspects. Theor. Appl. Genet., 73, 625-629.

CUGUEN, J., WATTIER, R., SAUMITOU-LAPRADE, P., FORCIOLI, D., MORCHEN, M., VAN DIJK, H. AND VERNET, P. 1994. Gynodioecy and mitochondrial DNA polymorphism in natural populations of Beta vulgaris ssp. maritima. Génét. Sél. Évol., 26, S87-S101.

FOX, T. D. AND LEAVER, C. J. 1981. The Zea mays mitochondrial gene coding cytochrome oxidase subunit II has an intervening sequence and does not contain TGA codons. Cell, 26, 315-323.

FRANK, S. A. 1989. The evolutionary dynamics of cytoplasmic male sterility. Am. Nat., 133, 345-376.

GOUYON, P.-H. VICHOT, F. AND VAN DAMME, J. M. M. 1991. Nuclear-cytoplasmic male sterility: single point equilibria versus limit cycles. Am. Nat., 137, 498-514.

HANSON, M. R. 1991. Plant mitochondrial mutations and male sterility. Ann. Rev. Genet., 25, 461-486.

ISAAC, P. G., BRENNICKE, A., DUNBAR, S. M. AND LEAVER, C. J. 1985a. The mitochondrial genome of fertile maize (Zea mays L.) contains two copies of the gene encoding the alpha-subunit of the F1-ATPase. Curr. Genet., 10, $321-328$.

ISAAC, P. G., JONES, V. P. AND LEAVER, C. J. 1985b. The maize cytochrome c oxidase subunit I gene: sequence, expression and rearrangements in cytoplasmic malesterile plants. $E M B O J ., 4,1617-1623$.

KEMBLE, R. J., GUNN, R. E. AND FLAVELL, R. B. 1983. Mitochondrial DNA variation in races of maize indigenous to Mexico. Theor. Appl. Genet., 65, 129-144.

KIANG, A. S., CONNOLLY, V., MCCONNELL, D. J. AND KAVANAGH, T. A. 1993. Cytoplasmic male sterility (CMS) in Lolium perenne L. 1. Development of a diagnostic probe for the male-sterile cytoplasm. Theor. Appl. Genet., 86, 781-787.

KOELEWIJN, H. P. AND VAN DAMME, J. M. M. 1995a. Genetics of male sterility in gynodioecious Plantago coronopus. 1. Cytoplasmic variation. Genetics, 139, 1749-1758.

KOELEWIJN, H. P. AND VAN DAMME, J. M. M. 1995b. Genetics of male sterility in gynodioecious Plantago corono- pus. 2. Nuclear genetic variation. Genetics, 139, $1759-1775$.

KREIKE, C. M., DE KONING, J. R. A. AND KRENS, F. A. 1990. Non-radioactive detection of single-copy DNA-DNA hybrids. Plant Mol. Biol. Rep., 8, 172-179.

LEVINGS, C. S., III AND PRING, D. R. 1977. Diversity of mitochondrial genomes among normal cytoplasms of maize. J. Hered., 68, 350-354.

MCNAY, J. W., PRING, D. R. AND LONSDALE, D. M. 1983. Polymorphism of mitochondrial DNA ' $S$ ' regions among normal cytoplasms of maize. Plant Mol. Biol., 12, 177-189.

NEGRUK, V. I. AND KAUSHIK, N. K. 1988. Structural variation in Vicia faba mitochondrial genomes. Theor. Appl. Genet., 76, 587-592.

PRING, D. R., LONSDALE, D. M., GRACEN, V. E. AND SMITH, A. G. 1987. Mitochondrial DNA duplication/deletion events and polymorphism of the $\mathrm{C}$ group of male sterile maize cytoplasms. Theor. Appl. Genet., 73, 646-653.

RIESEBERG, L. H., VAN FOSSEN, C., ARIAS, D. AND CARTER, R. L. 1994. Cytoplasmic male sterility in sunflower: origin, inheritance, and frequency in natural populations. J. Hered., 85, 233-238.

ROGERS, S. O. AND BENDICH, A. I. 1985. Extraction of DNA from milligram amounts of fresh, herbarium and mummified plant tissues. Plant Mol. Biol., 5, 69-76.

ROUWENDAL, G. J. A., VAN DAMME, J. M. M. AND WESSELS, J. G. H. 1987. Cytoplasmic male sterility in Plantago lanceolata L.: differences between male-sterile cytoplasms at the DNA and RNA level. Theor. Appl. Genet., 75, 59-65.

SAUMITOU-LAPRADE, P., ROUWENDAL, G. J. A., CUGUEN, J., KRENS, F. A. AND MiChaElis, G. 1993. Different CMS sources found in Beta vulgaris ssp. maritima - mitochondrial variability in wild populations revealed by a rapid screening procedure. Theor. Appl. Genet, , 85, 529-535.

VAN DAMME, J. M. M. 1983. Gynodioecy in Plantago lanceolata L. II. Inheritance of three male sterility types. Heredity, 50, 253-273.

VAN DAMME, J. M. M. AND VAN DELdEN, w. 1982. Gynodioecy in Plantago lanceolata L. I. Polymorphisms for plasmon type. Heredity, 49, 303-318.

VERWOERD, T. C., DEKKER, B. M. M. AND HOEKEMA, A. 1989. A small-scale procedure for the rapid isolation of plant RNAs. Nucl. Acids Res., 17, 2362.

WElHE, A., DUDAREVA, N. A., VEPREV, S. G., MALETSKY, S. I., MELZER, R., SALGANIK, R. I. AND BORNER, T. H. 1991. Molecular characterization of mitochondrial DNA of different subtypes of male-sterile cytoplasms of the sugar beet Beta vulgaris L. Theor. Appl. Genet., 82, 11-16.

YAMAGISHI, H. AND TERACHI, T. 1994. Molecular and biological studies on male-sterile cytoplasm in the Cruciferae. 1. The origin and distribution of ogura male-sterile cytoplasm in Japanese wild radishes (Raphanus sativus L.) revealed by PCR-aided assay of their mitochondrial DNAs. Theor. Appl. Genet., 87, 996-1000. 